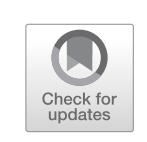

\title{
Sustainability, Disaster Risk Reduction and Climate Change Adaptation: Building from the Bottom Up - A South African Perspective from the Small-scale Fisheries Sector
}

\section{Merle Sowman and Xavier Rebelo}

\section{Introduction}

South Africa, like many countries in Africa, is a signatory to various international multilateral agreements such as the UN 2030 Agenda for Sustainable Development and the Sustainable Development Goals (SDGs), the Paris Agreement (2016), Sendai Framework for Disaster Risk Reduction (2015-2030) and, more recently, the Voluntary Guidelines for Securing Small-scale Fisheries (FAO, 2015), so as to chart a more sustainable and climate-appropriate development pathway. Consequently, South

M. Sowman $(\bowtie)$

Environmental \& Geographical Science Department and Environmental Evaluation Unit, University of Cape Town, Cape Town, South Africa e-mail: merle.sowman@uct.ac.za

X. Rebelo

Environmental \& Geographical Science Department, University of Cape Town, Cape Town, South Africa 
Africa has developed policies and strategies to promote sustainable development and respond to climate change and its impacts. Reducing and managing disasters are also dealt with in the suite of policies and legislation that seeks to manage and reduce risk and vulnerability, especially amongst the poor and marginalised sectors of society. Climate change is one factor that is increasingly contributing to disaster risk.

Coastal fishing communities who depend on marine resources for food and livelihoods are a particularly vulnerable sector (Allison et al., 2005, 2009; Dolan \& Walker, 2006; Kalikoski et al., 2018). Worldwide, over 200 million people depend on SSFs for their livelihoods, and this sector employs approximately $90 \%$ of the world's capture fisheries and fish workers (Ruiz-Díaz et al., 2020). Due to a range of factors, this sector is among the poorest and most marginalised in the world. Firstly, the nature of fishing is largely unpredictable and subject to a range of environmental factors such as resource availability, seasonality, weather and climate (FAO, 2015). Other factors such as macroeconomic and political factors, unstable institutional arrangements, weak local-level organisations and limited government support add to their vulnerability context (Allison et al., 2005; FAO, 2015). In addition, SSFs are subject to a myriad of pressures on their fishery system including: the impacts of industrial and even recreational fishing; the prevalence of illegal, unreported and unregulated (IUU) fishing; restrictions on access to traditional fishing grounds and other natural resources; poor infrastructure; lack of facilities and basic services, and limited social protection (Allison et al., 2005; Bennett et al., 2020). Thus, they are particularly vulnerable to the effects of climate change and natural and human-induced disasters.

Fishing communities are often at the front line of climate change due to their geographic location in high-risk coastal areas. This makes them particularly vulnerable to disasters such as floods, coastal erosion, and storms at sea (Dolan \& Walker, 2006; Kalikoski et al., 2018). Changes in sea temperatures and oceanic chemistry will have an impact on fish migration, distribution, recruitment, growth, abundance and predatorprey relationships, which will in turn affect the livelihoods and wellbeing of coastal communities (McIlgorm et al., 2010). Shifts in species abundance and movement of fish means that fishers may need to travel further out to sea, or venture out in marginal weather conditions, placing them 
at great risks, often without or with limited safety equipment. These fishers are deeply connected to the ocean and observe and experience environmental changes and the impacts that result from these changes on a daily basis. They hold immense knowledge about changing environmental conditions and are well placed to contribute knowledge and ideas about adaptation strategies that are required to reduce risk, build resilience and 'leave no one behind' (Mohammed et al., 2020). Yet, they are seldom consulted about their experience and knowledge of environmental change and risks to their livelihoods, or invited to contribute to policy and strategy formulation processes. While their experience and knowledge may be relevant to a local context, the ideas generated at this level are likely to produce proposals for local socio-economic development, climate adaptation and disaster risk reduction (DRR) that are locally appropriate and supported. Furthermore, the cumulative knowledge from fishing communities located around the coast could provide information and insights regarding socio-economic development needs, risk reduction and climate adaptation strategies that inspire a more integrated and locally grounded approach to the development of national policies, strategies and plans to address coastal risk.

While the advent of democracy in South Africa catalysed a massive law reform process that led to the promulgation of a plethora of progressive policies and laws across all sectors, the implementation of policy and law has been weak (Munzhedzi, 2020). The fields of sustainable development, climate change and disaster risk reduction are governed by different policies and laws and are the responsibility of different government departments and governance actors operating at different levels of government. Despite calls for integration, coordination, cooperative governance and involvement of civil society in all three arenas, there is limited integration across these endeavours. Research on the vulnerability of small-scale fishers to various threats and stressors, including climate change, provides a useful lens for examining the relationships between these interrelated fields and reveals how governance actors respond to coastal communities at risk and their quest for sustainable livelihoods.

This chapter reviews the policies, strategies and plans relevant to sustainable development, disaster risk management and climate change adaptation (CCA) in South Africa and examines the extent to which 
there is policy alignment and institutional cooperation to integrate these complementary agendas in the coastal environment, with particular focus on coastal fishing communities. Drawing on extensive involvement in the small-scale fisheries policy development and implementation process in South Africa over several years (Sowman et al., 2014a; Sowman et al., 2014b; Sowman \& Sunde, under review), as well as a research project concerned with assessing vulnerability of fishing communities to climate change and building resilience to adapt to change (Raemaekers \& Sowman, 2015; Sowman \& Raemaekers, 2018; Sowman, 2020), the chapter highlights a number of issues regarding the ongoing vulnerability of coastal fishing communities to climate change and associated impacts, and how these undermine the ability to pursue a sustainable development pathway. It then reflects on the findings from a number of communitybased vulnerability assessments conducted in South Africa and argues that communities are best placed to identify and help shape local development and adaptation plans, based on their knowledge and experience. How this knowledge gets integrated both vertically and horizontally into formal government planning and decision-making processes, however, and leads to implementation of projects and plans that yield tangible results, remains a challenge.

\section{South Africa's Policy and Legal Framework for Sustainable Development, Climate Change and Disaster Risk Reduction}

\section{Introduction}

South Africa has a sophisticated and progressive policy and legal framework for sustainable development, climate change governance and disaster risk reduction (DRR) and management (DRM). The advent of democracy in South Africa ushered in a new constitutional dispensation, spearheaded by the promulgation of the Constitution in 1996 (RSA, 1996). The Constitution is underpinned by human rights principles and seeks to redress past injustices and promote substantive equality, generating a 
'window of political opportunity' to remould the existing apartheid legislation and policy in a manner that directly confronts the legacy of apartheid (Glavovic, 2006). All policies, legislation, strategies and action plans are now required to be formulated in terms of, and measured against, constitutional rights and provisions. The environmental right, contained within the Bill of Rights, guarantees everyone the right to an environment that is not harmful to their health or wellbeing, and requires the State, through reasonable legislative and other measures, to protect the environment, ensuring that conservation is promoted and that pollution and ecological degradation are prevented. Ultimately, all laws and policies must 'secure ecologically sustainable development, while at the same time promote justifiable economic and social development' (RSA, 1996, section 24). Human rights, including the environmental right and its association with promoting sustainable development, as enshrined in the Constitution, thus played a significant role in influencing environmental (in the broadest sense of the term) policies and laws. Based on these constitutional imperatives and South Africa's adoption of various international multilateral agreements such as the SDGs, the Paris Agreement and Sendai Framework for Disaster Risk Reduction (2015-2030), legislation, as well as various policies, strategies, management and action plans have been developed to address the commitments to these agreements.

\section{National Strategy for Sustainable Development}

South Africa's National Strategy for Sustainable Development and Action Plan 2011-2014 (NSSD1) builds on the 2008 National Framework for Sustainable Development and several initiatives to address issues of sustainability in South Africa. It presents an understanding of sustainable development and provides a high-level roadmap for strategic sustainable development. Strategic priorities include, inter alia, to enhance effective governance and institutional structures and mechanisms to achieve sustainable development, and to effectively adapt to and manage climate change impacts through interventions that build and sustain South Africa's social, economic and environmental resilience and emergency response capacity. The NSSD1 identifies particular adaptation 
interventions that are relevant or targeted at coastal communities in furtherance of this objective. These interventions include the introduction of development restrictions in the coastal zone, the maintenance of ecosystems that act as buffers against natural disasters, improved disaster management systems, adaptation plans at the local level and the bolstering of the adaptation capacity of communities. The NSSD1 also includes three 'process principles' that are intended to guide the implementation of its listed interventions. The second of these principles requires that the recommended interventions be underpinned by consultation and participation (DEA, 2011).

\section{National Environmental Management Act}

South Africa's umbrella environmental legislation, the National Environmental Management Act No. 107 of 1998 (NEMA), contains a set of 'environmental management principles' which give expression to the principle of sustainable development and are intended to guide the formulation of environmental policy and decision-making (Kidd, 2013). The NEMA advocates an integrated and co-ordinated approach to decision-making and the promotion of collaborative platforms for harmonising policies, legislation and actions pertaining to the environment. Whilst the NEMA principles and provisions do not explicitly refer to climate change, the NEMA does make provision for the circumvention of an environmental authorisation in terms of a listed activity in order to prevent or contain an emergency situation, which includes a 'disaster', as defined in the Disaster Management Act (DMA) (section 30A(7)). Importantly, the NEMA also establishes that 'sensitive, vulnerable, highly dynamic or stressed ecosystems, such as coastal shores, estuaries, wetlands, and similar systems require specific attention in management and planning procedures' (section $2(4)(\mathrm{r})$ ). 


\section{Coastal Management}

Shortly after the promulgation of the NEMA, and in line with the aforementioned recommendation, South Africa's first integrated coastal management (ICM) policies and legislation emerged in the configurations of the White Paper for Sustainable Coastal Development of 2000 (White Paper) and the Integrated Coastal Management Act No. 24 of 2008 (the ICMA). South Africa's coastal policy and legislative framework for promoting sustainable coastal development and protecting coastal ecosystems and communities has been heralded as progressive (Sowman \& Malan, 2018). Both the White Paper and the ICMA were instrumental in transforming the previous biocentric and bureaucratic approach to coastal management into a participatory approach, underscored by human development imperatives and the need to promote sustainable livelihoods through equitable access to coastal resources and commons (Glavovic, 2006).

Noticeably, the ICMA places considerable emphasis on the public nature of the coast and conveys an intention to enhance and extend equitable access to the coastal commons, while concurrently preserving the integrity of the coastal ecosystem. Governance under this new coastal management paradigm calls for a participatory and adaptive management approach, which seeks to integrate policies and actions across scales as well as recognise the interlinkages between environmental processes and human activities (Glavovic, 2016; Sowman \& Malan, 2018). The development and application of strategic guidance documents, known as coastal management programmes (CMPs), at different levels of governance, is seen as central to informing planning and decision-making. The hierarchical relationship between CMPs allows for the formulation of a strategic and overarching National CMP, followed by more localised CMPs that accommodate increasing degrees of local management detail. These CMPs set out priority areas including priorities relevant to reducing coastal risk. Priority 1 of the National CMP, for example, refers to effective planning for coastal vulnerability to global change, including climate change. In addition, the ICMA includes various mechanisms that can be harnessed to reduce risk to coastal ecological systems and 
communities such as the declaration of coastal protection zones, coastal public property, special management areas and demarcation of management lines (Sowman \& Malan, 2018). Collaborative governance is key to the implementation of the ICMA, which promotes the establishment of both formal and informal institutions for coastal management, in addition to partnerships among a variety of role players in the quest for improved coastal governance (RSA, 2008, preamble).

\section{Disaster Risk Management}

A new paradigm for disaster management has also emerged, with a shift from a reactive approach to implementing post-disaster emergency relief measures to a more holistic and integrated, proactive, pre-disaster planning approach. The Disaster Management Act No. 67 of 2002 (DMA), as amended, and the National Disaster Management Framework (NDMF) of 2005 aim to reduce, prevent and/or mitigate risks associated with disasters and their severity through rapid and effective responses, as well as post-disaster recovery and pre-disaster planning. The DMA calls for the establishment of 'disaster management centres' at the national, provincial and municipal levels. The objective of these disaster management centres is to promote a coordinated and integrated approach to disaster management, with a particular emphasis on adaptation and mitigation strategies (section 9).

The NDMF constitutes the policy instrument specified by the DMA to provide 'a coherent, transparent and inclusive policy on disaster management appropriate for the Republic as a whole' (section 7(1)). While the DMA provides guidance on the nature and approach to disaster risk management, the NDMF delineates how coherence, transparency and inclusive disaster management, as well as cooperation across spheres of government, will be attained. This includes the establishment of an Intergovernmental Committee for Disaster Management, the establishment of disaster management centres, as well as advisory forums at the national, provincial and local level.

Although the coastal zone is not explicitly mentioned in the DMA, the NDMF, in the very first paragraph, makes specific reference to South 
Africa's 'extensive coastline' and 'coastal threats' as significantly increasing the potential for disaster risk. This understanding identifies the coast as a strategic area in which to focus and strengthen disaster risk management efforts in South Africa. In this regard, the NDMF identifies a variety of risks and disasters that may unfold in South Africa and prioritises developmental measures that decrease the vulnerability of disaster-prone areas and communities. The NDMF is intended to guide the subsequent formulation of provincial and municipal disaster management frameworks and strategies.

Since municipalities are at the forefront of coastal disasters, it is incumbent on them to ensure that coastal risk and disaster management responses (both before, during and after a disaster) are appropriately integrated into their local integrated development plans (van Niekerk, 2006; Coburn et al., 1991). The NDMF lists various 'planning points' or requirements that must be considered by national, provincial and municipal government in their disaster risk management initiatives. Central among these is that disaster risk management initiatives will be more effective if they are the result of deliberative and participatory processes, which include local knowledge and expertise. Consequently, disaster risk management planning must always involve the active and constructive consultation between all at-risk sectors, communities and role players (DCGTA, 2005, section 3.3.1.3; RSA, 2002, section 7(2)(f)).

\section{Climate Change}

The 2011 National Climate Change Response White Paper sets the objective to effectively manage inevitable climate change impacts through interventions that build and sustain South Africa's social, economic and environmental resilience and emergency response capacity. The Paper proposes a strategic approach that is: needs-driven and customised; developmental; transformational; empowering and participatory; dynamic and evidence-based; balanced and cost effective, and integrated and aligned. This vision is informed by the principles established in the Constitution, the Bill of Rights, the NEMA, the Millennium 
Development Goals and the United Nations Framework Convention on Climate Change (UNFCCC).

The Paper is cognisant of the fact that coastal human settlements are extremely vulnerable to sea-level rise, flooding, coastal erosion and increased frequency and intensity of coastal storms. In response to these threats, the Paper specifies the need for enhanced disaster risk reduction and disaster risk managment as well as a succinct approach to adaptation. The Paper also identifies that adaptation responses have a strong local flavour and require the development of detailed bottom-up governance approaches that incorporate the participation of both local communities and government. As such, the Paper acknowledges the vital role that local government plays in addressing climate change-related issues.

The 2018 Draft Climate Change Bill provides for a coordinated and integrated approach to addressing climate change impacts, through engaging actors across government scales, and is underpinned by the principles of co-operative governance. The Bill aims to enhance adaptive capacity, bolster resilience and reduce vulnerability to climate change, and places great emphasis on institutional arrangements at the provincial and municipal level. A central policy tool proposed by the Bill is the formulation of a National Environmentally Sustainable Framework, which will delineate the appropriate mechanisms, systems and procedures to facilitate in the achievement of the objectives of the Bill. The Bill also makes provision for the establishment of 'Committees on Climate Change' at the national and provincial tiers of government.

The National Climate Change Adaptation Strategy (NCCAS) provides the necessary guidance to government actors across national, provincial and municipal scales in response to climate change. The NCCAS serves as South Africa's National Adaptation Plan in terms of the country's international obligations, as espoused in the Paris Agreement under the UNFCCC. The strategy seeks to facilitate greater coherence and coordination between various stakeholders, including governments, nongovernmental organisations, the private sector and local communities, in strengthening climate resilience, and to integrate the national disaster risk management framework into climate change preparedness, response and recovery. The NCCAS advocates for the inclusion and strengthening 
of adaptive capacity and resilience to climate change in national, provincial and municipal disaster management plans. The implementation of the adaptation strategies contained in the NCCAS is to be guided by a set of listed principles and key elements for adaptation and climate resilience. The NCCAS promotes the principles of participatory governance, and reaffirms that climate change adaptation strategies must be underpinned by the active participation of a wide range of stakeholders, including government, civil society organisations, communities and the private sector.

\section{Small-Scale Fisheries Policy}

At a sector level, the Policy for the Small-scale Fisheries Sector in South Africa of 2012 (SSF policy) proposes a fundamental shift in the approach and philosophy to the governance of SSFs. This new approach is underpinned by human rights principles, community involvement, participation and socio-economic development (Sowman et al., 2014a; Sowman et al., 2014b). The SSF policy delineates a collection of governance principles that echo international best practice and key constitutional principles, and is steered by objectives that seek to redress the unequal distribution of resources for SSF communities.

A central tenet of the SSF policy is the co-management of marine resources, which entails a people-centred and community-orientated approach towards the devolution of management decisions on fishing communities. The SSF policy, in line with South Africa's international and regional agreements on developing sustainable fisheries, recognises the value of sustainable resource management and harvesting within SSF communities. While the SSF policy canvasses on issues of disaster relief in relation to the ability of fishers to access disaster relief assistance and social security schemes, and aims to enhance safety at sea through bettering labour standards, it does not explicitly list the DMA under the category of laws relevant to the SSF sector. Although the SSF policy recognises the particular vulnerability of SSF communities to climate change, the only mechanism through which this vulnerability is addressed in the SSF policy is through the establishment of technical and advisory support 
services, such as support hubs, where fishers may access research and findings on climatic conditions. A lack of engagement with the interlinkages between climate adaptation and sustainable development is surprising, provided the vulnerable geographical location and fragile socio-economic circumstances of SSF communities in South Africa.

\section{Coastal Fishing Communities in South Africa}

In South Africa, the fisheries sector contributes $<1 \%$ to the country's gross domestic product (GDP). Despite this relatively low contribution to GDP, it is an extremely important industry, especially in the Western Cape province, providing formal employment to approximately 28,000 people and supporting over 40,000 small-scale and subsistence fishers throughout South Africa (Sowman et al., 2014b, Sunde \& Erwin, 2020). To date, 350 fishing communities have been identified and registered along the entire $3000 \mathrm{~km}$ stretch of coast from the Orange River mouth on the Namibia border to Kosi Bay on the Mozambique border. These fishing communities are engaged in a wide range of fishing activities, from boat-based line fishing on the west coast of South Africa to intertidal harvesting along the eastern seaboard and customary trap fishing in the Kosi Bay lake systems in KwaZulu-Natal (Sowman et al., 2014a; Sunde et al., 2013). Despite their reliance on marine resources as a vital source of food and livelihoods, as well as an integral facet of their customary practices in parts of the country (Mbatha, 2018; Sowman \& Cardoso, 2010; Sunde et al., 2013), these fishers have a long history of exclusion and marginalisation from the fisheries governance regime (Isaacs, 2006; Sowman, 2006).

Failure of government to address the rights and needs of this sector in the new democratic dispensation led to protests and a legal action that resulted in a court ruling requiring the Minister to embark on a policyreform process that would give legal recognition and protection to this sector, and secure access rights for traditional fishers. After an extensive policy development process (2008-2012), the SSF policy was promulgated and amendments to the Marine Living Resources Act (1998) were enacted in 2014 (DAFF, 2012, 2014). However, the process of allocating 
rights and implementing the new SSF policy in coastal communities has been slow and fraught with difficulties (Sowman \& Sunde, under review). This slow roll-out of policy has entrenched the vulnerable position of many SSFs, largely due to worsening economic conditions in South Africa, high levels of unemployment, deepening poverty and the lack of social protection for this marginalised sector. Of course, the COVID-19 pandemic has laid bare the vulnerability of poor and marginalised peoples in South Africa and exposed the government's failures to protect and support its most vulnerable groups (Bond, 2020). A lack of political will to prioritise this hitherto neglected sector, as well as the slow pace of policy implementation, has meant that thousands of fishers remain outside of the legal process and risk fines and imprisonment if caught harvesting resources without a valid permit. Despite good intentions, the lack of human capacity and resources within the SSF Directorate in the Department of Environment, Fisheries and Forestry (DEFF), and the narrow interpretation of fisheries development and management, has meant that SSFs remain vulnerable and at risk to various threats and disasters (Sowman \& Sunde, under review).

\section{Findings}

Despite a progressive policy that gives legal recognition to SSFs in South Africa and a commitment to a rights-based, community-orientated approach that is inclusive and developmental (Sowman \& Sunde, 2021), underpinned by sustainable development principles, the socio-economic conditions that prevail in these coastal communities continue to affect the precarious nature of their livelihoods. Participation of the first author in the SSF policy development process (2008-2012) and in follow-up meetings, workshops and roundtable discussions on the implementation of the policy with fisher representatives and their social partners over several years, has highlighted how the vulnerability of this sector is exacerbated by climate change and, more recently, the COVID-19 pandemic (Sowman \& Sunde, under review). While the SSF policy was designed to provide legal recognition and protection to SSFs, ensure preferential access to coastal fishing communities, support the development of these 
fisheries, build local-level organisations and expand markets, thousands of coastal fishers do not have secure access to resources, and many communities still lack access to basic services and facilities (Sowman \& Sunde, under review). Of particular concern is the lack of social protection provided to small-scale fishers and the failure to ensure their right to food and access to resources to pursue a livelihood. Despite the commitment to an inclusive and developmental approach, the SSFs sector is managed by the Small-Scale Fisheries Directorate who are under-resourced and focused on resource allocation and management. Proposals for a more holistic and 'whole of government approach' that recognises the complexity of the SSF system and works collaboratively with fishers to manage resources and develop their fisheries have not been embraced.

Understanding how these various agendas play out in the SSF arena in South Africa was further informed by a series of vulnerability assessments conducted in five coastal fishing communities as part of a number of FAO-GEF-BCC-supported projects on understanding vulnerability to climate change and building resilience in coastal communities in the Benguela Current Large Marine Ecosystem (BCLME) region. The first phase of the project focused on developing a community-based vulnerability assessment tool to assess vulnerability of coastal communities to climate change. This assessment tool, known as the RVA tool (Raemaekers \& Sowman, 2015; Sowman \& Raemaekers, 2018), has been applied in fifteen fishing communities in the BCLME region (Sowman, 2020). In this chapter, we draw on the findings from the RVA workshops conducted in five fishing communities in South Africa and the follow-up work to develop adaptation strategies to address vulnerabilities associated with climate change. The RVA was conducted over a two-day period and was structured around a series of participatory exercises that sought to understand the local socio-ecological context with a particular focus on identifying environmental and climate-related stressors and changes, the impacts associated with these stressors and changes, and the adaptation strategies required to respond to these livelihood threats (Raemaekers \& Sowman, 2015; Sowman \& Raemaekers, 2018).

Table 8.1 provides a summary of the main threats to livelihoods identified by fishers in the workshops in South Africa, and lists the adaptation 
8 Sustainability, Disaster Risk Reduction and Climate Change...

Table 8.1 Livelihood threats and adaptation strategies

\begin{tabular}{|c|c|}
\hline Stressor/threat & Interventions and adaptation strategies \\
\hline \multicolumn{2}{|l|}{ Environmental/climate } \\
\hline \multirow{5}{*}{$\begin{array}{l}\text { Unpredictable weather and seasonal } \\
\text { changes (including rougher seas, } \\
\text { changing wind patterns and ocean } \\
\text { currents) }\end{array}$} & $\begin{array}{l}\text { Increased interaction between SSF and } \\
\text { scientists to bolster knowledge on } \\
\text { climate variability and change }\end{array}$ \\
\hline & $\begin{array}{l}\text { Safety at Sea training and } \\
\text { establishment of Safety at Sea system }\end{array}$ \\
\hline & $\begin{array}{l}\text { Increased access to information and } \\
\text { communication technologies (ICTs) for } \\
\text { weather forecasts }\end{array}$ \\
\hline & $\begin{array}{l}\text { Explore supplemental livelihoods (e.g. } \\
\text { tourism, marine products) }\end{array}$ \\
\hline & Upgrade boats to manage rough seas \\
\hline \multirow[t]{4}{*}{ Declining individual catches } & $\begin{array}{l}\text { Explore harvesting of other resources } \\
\text { (seaweeds etc.) }\end{array}$ \\
\hline & $\begin{array}{l}\text { Monitor and record catches to assist } \\
\text { with management }\end{array}$ \\
\hline & $\begin{array}{l}\text { Develop supplemental livelihoods (e.g. } \\
\text { mariculture) }\end{array}$ \\
\hline & $\begin{array}{l}\text { Improve implementation of regulations } \\
\text { and compliance }\end{array}$ \\
\hline \multirow[t]{3}{*}{$\begin{array}{l}\text { Increasing levels of pollution and } \\
\text { environmental degradation }\end{array}$} & $\begin{array}{l}\text { Community-government partnerships } \\
\text { to address waste collection/recycling }\end{array}$ \\
\hline & $\begin{array}{l}\text { Strengthen networks with scientists and } \\
\text { lawyers to challenge polluting and } \\
\text { damaging activities }\end{array}$ \\
\hline & $\begin{array}{l}\text { Better monitoring and compliance by } \\
\text { government }\end{array}$ \\
\hline \multirow[t]{3}{*}{ Shorter, later fishing season } & $\begin{array}{l}\text { Explore markets interested in diversified } \\
\text { catches and undervalued species }\end{array}$ \\
\hline & $\begin{array}{l}\text { Training on quality control and seek } \\
\text { access to cold-chain infrastructure }\end{array}$ \\
\hline & $\begin{array}{l}\text { Better collaboration with DAFF re } \\
\text { access to alternative resources }\end{array}$ \\
\hline \multicolumn{2}{|l|}{ Governance } \\
\hline \multirow[t]{2}{*}{ Weak local-level organisation } & $\begin{array}{l}\text { Develop local fisher associations or } \\
\text { fisher co-operatives }\end{array}$ \\
\hline & $\begin{array}{l}\text { Training to run co-op effectively (e.g. } \\
\text { financial and business management } \\
\text { training) }\end{array}$ \\
\hline
\end{tabular}


Table 8.1 (continued)

\begin{tabular}{|c|c|}
\hline Stressor/threat & Interventions and adaptation strategies \\
\hline $\begin{array}{l}\text { Lack of communication with and } \\
\text { support from government }\end{array}$ & $\begin{array}{l}\text { Set up and improve communication } \\
\text { channels with government } \\
\text { Facilitate fisher-scientist exchanges to } \\
\text { improve knowledge base } \\
\text { Increase collaboration between } \\
\text { government and fishers through } \\
\text { co-management structures } \\
\text { Prioritise the implementation of the SSF } \\
\text { policy }\end{array}$ \\
\hline Socio-Economic & \\
\hline $\begin{array}{l}\text { Lack of equipment and support for } \\
\text { infrastructure }\end{array}$ & $\begin{array}{l}\text { Explore supplemental livelihoods (e.g. } \\
\text { tourism, marine products) } \\
\text { Improve infrastructure, facilities and } \\
\text { security at harbour }\end{array}$ \\
\hline $\begin{array}{l}\text { Lack of markets and unequal access } \\
\text { to markets }\end{array}$ & $\begin{array}{l}\text { Development of local products and } \\
\text { increased access to markets } \\
\text { Training and skills development in small } \\
\text { business and marketing } \\
\text { Develop/implement a cold-chain } \\
\text { storage and quality control system to } \\
\text { maximise markets and promote } \\
\text { undervalued species }\end{array}$ \\
\hline $\begin{array}{l}\text { Competition from commercial and } \\
\text { recreational fishers, and mining } \\
\text { sector }\end{array}$ & $\begin{array}{l}\text { Obtain compensation for habitat } \\
\text { damage (e.g. from mining) } \\
\text { Strengthen policies and regulations to } \\
\text { protect marine resources } \\
\text { Improve monitoring and enforcement } \\
\text { of commercial fishing and mining } \\
\text { activities }\end{array}$ \\
\hline
\end{tabular}

actions and strategies that they considered appropriate and 'doable' to address vulnerabilities and build resilience. Although the focus was on identifying adaptation strategies to address climate variability and change, many of the strategies were relevant to addressing threats to livelihoods and building resilience to deal with their vulnerability context more broadly.

Although the focus of the project was on understanding vulnerability of coastal fishing communities to climate change, it became clear in the workshops that climate change could not be discussed in isolation of the 
myriad of other stressors facing these communities, including their preexisting vulnerabilities, many of these associated with discriminatory apartheid legislation that excluded them from the fisheries sector and other spheres of economic life. A list of basic needs including housing, education, health facilities etc. were mentioned in all workshopsx, and stressors associated with poverty were ever present. Nonetheless, for many fishers, changing environmental conditions that affect fishing was an issue of concern in all communities. These changes included unpredictable weather and seasonal changes (including rougher seas, changing wind patterns and ocean currents), fish being further out at sea and reduced individual catches. Threats from other sector activities, in particular mining and commercial fishing activities, as well the pollution arising from these activities, were identified as significant threats to their livelihoods.

Lack of communication with and support from government was considered a further key threat to livelihoods and, as decisions were topdown, local fishers were seldom consulted and mechanisms for communication were limited. Weak local-level organisations were also identified as negatively affecting fishers' livelihoods through inability to access information, engage with government, obtain permits and explore better market opportunities. Key socio-economic threats to livelihoods were identified as lack of equipment and support for infrastructure, lack of markets and unequal access to markets due to powerful marketers, as well as competition for resources from other sectors.

In considering how to deal with these threats, including threats associated with climate change and possible disasters, fishers identified a number of interventions and adaptation strategies which they see as necessary to be able to respond to these threats and adapt to climate change. Many of the interventions focused on government fulfilling their monitoring, regulatory and management functions in terms of other sectors, as well as providing the necessary infrastructure support for fishing activities, such as cleaning facilities at landing sites. The adaptation strategies identified can be grouped into five main categories: namely, strengthening local organisations (e.g. fisher co-operatives), development of supplementary or alternative livelihoods, skills training and capacity development, 
improving safety at sea and access to better ICTs for weather forecasts, and improving market access and opportunities.

Strengthening local organisations and building institutional capacity was recognised as critically important in order to address stressors and respond more effectively to climate change impacts and disaster risks. Building fisher organisations and establishing local co-operatives were identified as urgent actions by South African fishing communities. Communities identified the nature of support required and listed potential government departments, development agencies, NGOs and tertiary institutions that could assist them. In all communities, various types of skills training associated with product beneficiation, marketing of products, business and financial management, the use of mobile phone apps (developed by ABALOBI ICT4 fisheries) to record and market catches, as well as training in food hygiene and safety, were also identified. In response to various environmental stressors, many participants listed supplemental livelihood activities (e.g. local tourism, mariculture), as an important adaptation strategy. These alternative livelihoods largely focused on exploring supplemental livelihoods from the sea, whether through the targeting of alternative resources (e.g. seaweeds), mariculture development or tourism. Improving product beneficiation, preserving various marine products such as mussels, and expanding markets were also identified as key actions for building resilience.

Improving safety at sea was identified as an important adaptation strategy. This included better and safer equipment such as global positioning systems (GPS), vessel monitoring systems (VMS), access to the internet and, in cases where certain fish species were only found further out at sea, bigger and more robust boats. Fishers also required access to early warning systems which they argued was the responsibility of government. Currently, in all cases, only those fishers with access to the internet can obtain long-term weather forecasts.

In nearly all the workshops, participants stressed the importance of taking forward the identified adaptation strategies and actions. Fishers looked to external stakeholders, such as NGOs and researchers, to play a facilitating role in bringing together the relevant government departments and other parties in order to turn adaptation proposals into action plans. Communities were clear that support from international funding 
agencies was needed, since government was unlikely to be in a position to fund many of the proposals.

\section{Discussion}

Relying on the SSF sector in South Africa as a case study, this final section discusses some of the challenges in bringing the various agendas, namely sustainable development, climate change and DRR together. It then reflects on what NGOs and local communities, and in particular their local knowledge, can contribute to informing policies, adaptation and management plans in these arenas.

\section{Lack of a Holistic and Integrated Approach}

Understanding the vulnerability context of coastal fishing communities, including the various factors that shape their capacity to cope with and adapt in the face of poverty, and increasing threats associated with climate change and natural and human-induced disasters, requires a historical perspective, as well as a holistic and integrated approach (Barange et al., 2018). SSF communities in South Africa have been neglected for several decades and their pre-existing vulnerabilities cannot be ignored when addressing climate change threats and disasters. These communities face a myriad of stressors and threats, including socio-economic challenges, governance failures and, more recently, threats associated with climate change (Sowman \& Raemaekers, 2018). These stressors (old and new) often act in concert, driving a complex web of vulnerability amongst communities (Sowman \& Sunde, under review). Thus, assessing vulnerability, building adaptive capacity for climate change and preparing proactively for disasters requires a recognition of these interlinkages among governance actors. It also requires an appreciation of the differential impact that climate change may have on different communities and groups.

Clearly, a one-size-fits-all approach is not appropriate. Nor will a sector response be appropriate in most cases (e.g. a fisheries management 
department dealing with the ongoing threat of coastal flooding at a landing site due to increased winter storms). Given the complex nature of these problems, there is a need for a multi-sector and broader governance response. This requires government to go beyond its narrow mandate and work more holistically and collaboratively with other departments and enlist the expertise and support of NGOs, researchers and other actors, as appropriate. While most policies and strategies relevant to sustainable development, climate change and DRR advocate this more holistic and integrated approach, in practice a top-down, sector-specific and regulatory approach is being adopted.

\section{Lack of Alignment and Policy Coherence at National Level}

Although South Africa boasts an extensive assemblage of sustainable development, climate change adaptation and disaster risk management legislation and policy, effective climate change adaptation and disaster risk reduction is severely hampered by a lack of policy coherence and alignment between government departments and among different spheres of government. Whilst sustainable development and climate change is generally considered to fall within the environmental ambit, disaster risk reduction is considered an area of broader concern. The DEFF is charged with the overall implementation of sustainable development, climate change and coastal policy, while the Department of Cooperative Governance and Traditional Affairs (DCGTA) is responsible for disaster risk management. Accordingly disaster risk reduction, has been sluggish in connecting risk reduction associated with extreme events to climate change adaptation.

Climate adaptation is largely considered an environmental issue in South Africa, thereby relegating its importance in relation to the plethora of socio-economic issues that compete for primacy. While the concept of sustainable development offers opportunities to integrate the facets of environmental protection, economic development and social upliftment, progress on formulating the second National Strategy for Sustainable Development (NSSD2), which was expected to come to fruition between 
2015 and 2020, has not occurred. While policy generation on sustainability appears to have stalled, issues of socio-economic development are increasingly being prioritised over environmental integrity, severely constraining future adaptation options for climate variability and associated increases in disastrous events.

South Africa's economic downturn, exacerbated by the COVID 19 pandemic, as well as its embrace of the 'Blue Economy' agenda, has led to an aggressive push to grow and revive the South African economy through a reliance on energy-intensive industries like oil and gas, mining, shipping and mariculture. Coupled with the national electricity supply crisis, there is considerable pressure on government departments like the Department of Mineral Resources (DMR) which aims to promote economic growth through the development of mineral resources and the energy sector, and exploit natural resources for socio-economic upliftment. Although the DMR has committed to sustainable development in the mining and energy sector and is obliged to comply with the environmental authorisation procedures before the issuing or granting of rights and permits, it interprets sustainable development in a manner that prioritises socio-economic development above environmental imperatives. Despite the disjuncture between the environmental impacts of mining and South Africa's commitments to mitigating climate change, various permits to mine along the West Coast of South Africa have recently been issued, while further rights for oil and gas exploration are awaiting approval. This reveals contradictions within national government regarding the interpretation of sustainable development principles, which is further evidenced by the divergent framings and interpretations of the concepts between government departments. Although the DEFF is responsible for the implementation of sustainability and climate adaptation objectives, it has failed to halt the activities of extractive industries, undermining its policies and strategies to mitigate climate change and adapt in the face of climate variability. Thus, while sustainable development and climate adaptation need to be integrated into the policies and strategies of all government departments, important questions arise as to which departmental framing and interpretation of these imperatives dominates. The need for a uniform approach to implementing these concepts within the strategies of all government departments is particularly 
necessary in ensuring that environmental concerns are not overlooked as South Africa embarks on its Economic Reconstruction and Recovery Plan.

\section{Mismatch Between Policy Rhetoric and Implementation}

Much of South Africa's sustainability, disaster risk mangement and climate change legislation and policy is innovative and reflects the contemporary state of international thinking regarding these subject matters. However, as is the case with various legislative and policy initiatives in South Africa, effective implementation remains deficient (Kidd, 2013).

While the South African judiciary has endorsed the principle of interdependency and exhibited an acute awareness of the implications of climate change on the attainment of socio-economic development, translating this understanding into a practical reality remains challenging due to the fragmentation of government departments tasked with implementing climate change adaptation, disaster management and socio-economic strategies (Murcott, 2018; Schlosberg, 2013) The DEFF is the leading government department for the implementation of sustainable development and climate adaptation objectives and strategies in South Africa, however DEFF lacks the authority to influence other departments. The 'silo' mentality of government departments impedes the cross-pollination of sustainability, adaptation and disaster management imperatives within the strategies of departments tasked with implementing development objectives.

Although the vast majority of national government policies and frameworks for sustainable development, climate adaptation and disaster management acknowledge the critical role of local government for their implementation, they rarely endow municipalities with the resources and authority to meet national targets (Perine \& Keuck, 2018; Reddy \& Wolpe, 2017). In this regard, there is a substantial mismatch between the ambitious objectives set at the level of national policy and their implementation at the municipal level.

Climate adaptation and disaster risk managment are generally the responsibilities of the relevant department within municipalities, where 
such a department exists. However, rural and small municipalities may only have ad-hoc committees to manage environmental issues (Mokwena, 2009) or, in the case of disaster risk management, advisory forums to facilitate stakeholder participation. These departments are generally under-resourced and lack the authority to influence the mandates of departments dealing with transportation, energy, water and land-use planning, which are focused on deliverables and are tethered to sectoral plans and campaign promises. Thus, jurisdictional ambiguity exists between the various line functions at the local level, impeding action on the ground. In view of these resource and capacity constraints, it is challenging to envision opportunities to apply cooperative governance principles, integrated and coordinated disaster management, and stakeholder involvement, at the municipal level.

Thus, while the intricate web of policies continue to swell both in number and ambition, at the better funded and capacitated levels of national and provincial government, until the gap between policy rhetoric and implementation is effectively bridged at the local level, these frameworks will remain largely aspirational. Despite a strong emphasis on the involvement of local communities in the co-production of disaster risk managment and climate change adaptation initiatives, the reality of SSFs exhibits that converting policy rhetoric into practical reality is a 'field of struggle' (Glavovic, 2006).

\section{Role of NGOs and Other Actors in Facilitating Change and Building Resilience}

The apparent failure of the State to address the needs of and respond to the threats facing SSFs in South Africa, has increased their reliance on NGOs and other actors such as researchers. These social partners, including Masifundise Development Trust, Legal Resources Centre, ABALOBI $\mathrm{NPO}$ and many researchers, are involved in supporting SSFs in a variety of ways, such as in their efforts to claim rights to resources, gain information on policy and management decisions, improve local fisheries monitoring and management, gain access to better markets, build institutional capacity and local skills, and challenge government decisions that they 
consider to be unfair. Worldwide, ongoing distrust of and frustration with government authorities on the part of development and donor agencies has led to increased support for NGOs as facilitators of change, implementers of development projects and brokers of agreements (Murray \& Overton, 2011). NGOs and other social partners are certainly playing an increasing role in supporting SSFs in South Africa in these various ways. Communities see NGOs and other trusted social partners as better able to represent their interests and needs because they are more attuned to local socio-ecological contexts and mostly work with poor and marginalised communities.

Lessons from work in the SSF policy arena over the years and involvement in the vulnerability assessment and adaptation planning workshops reported in this chapter, suggest that NGOs and researchers are increasingly providing support (technical, legal, access to information, skills training, capacity building, facilitation, networking etc.) to SSF communities in view of the absence of government to address their vulnerability circumstances and fulfil their mandates. Where communities have existing relationships with researchers and NGOs, they are able to gain information and access to support and resources more easily than those communities that are not well networked. Through these networks, communities are able to work collaboratively with their NGO and research partners to seek funding for particular strategies that could deliver immediate benefits.

However, while NGOs and researchers can play an important role in facilitating information exchange, providing technical and other supports, securing funding and facilitating local development and climate adaptation plans, in order for these plans and strategies to be implemented, relevant government departments need to be involved. Critically, implementation of these proposals and/or adaptation strategies needs to be integrated into local-level planning and development processes, as well as elevated so as to contribute to various plans and strategies at the provincial and national levels. 


\section{Integrating Bottom-Up Local-Level Planning Both Vertically and Horizontally}

Local fishing communities are at the coalface of changing weather conditions and longer-term climate changes and bear the brunt of disasters (Dolan \& Walker, 2006; Kalikoski et al., 2018). Their observations and first-hand experiences of changing environmental conditions (and how these impact local fisheries and livelihoods) imply that they are well placed to identify strategies and pathways to build resilience and sustainable livelihoods (Raemaekers \& Sowman, 2015). Incorporating their knowledge, insights and proposals into various local, provincial and national plans and strategies concerned with sustainable development, climate change and disaster risk reduction, both horizontally and vertically, would ensure that policies, plans and strategies are grounded in local realities. These higher-level documents, informed by local-level experiences and knowledge, are likely to have more legitimacy and be more relevant and useful when applied at the local level.

While there is vast literature on the importance of mainstreaming information generated at the community-level into national-level processes, and several policy and strategy documents advocate for participation of local communities in policy and plan formulation, the practicalities of inserting local knowledge into national sustainable development plans, disaster risk management plans and climate change adaptation strategies, is a challenging task (Adhikari \& Taylor, 2012; Pahl-Wostl \& Knieper, 2014). Thus, NGOs and other social partners working with communities need to engage with relevant government actors at some stage in these local-level processes to ensure that plans and strategies generated at the local level, such as the community-based adaptation plans reported on in section 4, are integrated into local, provincial and national development plans, climate change strategies and disaster risk managment plans. This is necessary to ensure that community-based assessments and plans, facilitated by NGOs or researchers, are acted upon and lead to implementation. Working from the bottom up and integrating this local information into higher-level plans and strategies, often required 
by law, will give policy- and plan-makers first-hand insight into the realities experienced by communities at risk, their vulnerability context, the changing environmental conditions they experience, their needs and priorities, and their proposals for adapting to change and dealing with disasters. The plans and strategies emanating from such a bottom-up approach are likely to be more widely supported and realistic, and contribute to sustainable development goals (SDGs) than those imposed from the top down.

\section{Conclusion}

South Africa has developed an impressive suite of policies, strategies and laws to deal with commitments to sustainable development and addressing and managing climate change challenges and disaster risks. These national policies, however, are not well aligned or implemented in a coordinated and integrated manner. Nor are they attuned to the realities facing local communities. Our work in coastal communities in South Africa reveals the lack of policy alignment and limited coordination across government departments at all levels charged with oversight responsibilities for these endeavours. Failure to adopt a holistic and integrated approach, as well as mismatches between policy rhetoric and implementation practices, leave vulnerable communities exposed. Local communities working in partnership with NGOs and other social partners can contribute considerable knowledge and experience to these processes as they are experiencing the effects of climate change and disasters first-hand and have practical proposals for dealing with and adapting to climate change and promoting sustainable livelihoods. Although their experience and knowledge are based on their local environmental context, the ideas generated at this level are likely to produce proposals for local socio-economic development, climate adaptation and disaster risk reduction that are locally appropriate and supported. Incorporating this local knowledge into local development and sector plans as well as sustainable development and sector-specific policies, strategies and plans at the national level, would enhance understanding of the realities on the ground and lead to policies, strategies and plans that are more harmonised and more likely to be supported and implemented. 
Acknowledgements The authors wish to acknowledge the involvement of Dr Serge Raemaekers in the development of the vulnerability assessment tool and Drs Caitlynne Francis and Raemaekers for their facilitation and input on the project referred to in this chapter. The Food and Agriculture Organization of the United Nations (FAO), Benguela Current Convention (BCC) and the Global Environment Facility (GEF), as well as the National Research Foundation in South Africa, are acknowledged for supporting this research.

\section{References}

Adhikari, B., \& Taylor, K. (2012). Vulnerability and Adaptation to Climate Change: A Review of Local Actions and National Policy Response. Climate and Development, 4, 54-65.

Allison, E. H., Adger, W. N., Badjeck, M.-C., Brown, K., Conway, D., Dulvy, N. K., Halls, A., Perry, A., \& Reynolds, J. D. (2005). Effects of Climate Change on the Sustainability of Capture and Enhancement Fisheries Important to the Poor: Analysis of the Vulnerability and Adaptability of Fisherfolk Living in Poverty (Project No. R4778J). Fisheries Management Science Programme, Marine Resources Assessment Group/Department of Foreign and International Development.

Allison, E. H., Perry, A. L., Badjeck, M. C., Adger, W. N., Brown, K., Conway, D., Halls, A. S., Pilling, G. M., Reynolds, J. D., Andrew, N. L., \& Dulvy, N. K. (2009). Vulnerability of National Economies to the Impacts of Climate Change on Fisheries. Fish and Fisheries, 10(2), 173-196.

Barange, M., Bahri, T., Beveridge, M. C. M., Cochrane, K. L., Funge-Smith, S., \& Poulain, F. (Eds.). (2018). Impacts of Climate Change on Fisheries and Aquaculture: Synthesis of Current Knowledge, Adaptation and Mitigation Options (FAO Fisheries and Aquaculture Technical Paper No. 627) (628 pp). The Food and Agriculture Organization of the United Nations.

Bennett, N. J., Finkbeiner, E. M., Ban, N. C., Belhabib, D., Jupiter, S. D., Kittinger, J. N., Mangubhai, S., Scholtens, J., Gill, D., \& Christie, P. (2020). The COVID-19 Pandemic, Small-Scale Fisheries and Coastal Fishing Communities. Coastal Management, 48(4), 336-347. https://doi.org/10.108 0/08920753.2020.1766937

Bond, P. (2020). Covid-19 Attacks the Down-and-Out in South Africa. ESR Review: Economic and Social Rights in South Africa, 21(3), 4-9. 
Coburn, A. W., Spence, R. J. S., \& Pomonis, A. (1991). Vulnerability and Risk Assessment: Disaster Management Training Programme. UNDRO.

DAFF (Department of Agriculture, Fisheries and Forestry). (2012). Policy for the Small-Scale Fisheries Sector in South Africa. Government Gazette..

DAFF (Department of Agriculture, Fisheries and Forestry). (2014). Marine Living Resources Amendment at 5 of 2014. Government Gazette No. 37659.

DCGTA (Department of Cooperative Governance and Traditional Affairs). (2005). South African National Disaster Management Framework.

DEA (Department of Environmental Affairs). (2011). National Strategy for Sustainable Development and Action Plan (NSSD1) 2011-2014.

Dolan, A. H., \& Walker, I. J. (2006). Understanding Vulnerability of Coastal Communities to Climate Change Related Risks. Journal of Coastal Resources, 39, 1317-1324.

FAO (Food and Agricultural Organisation). (2015). Voluntary Guidelines for Securing Sustainable Small-Scale Fisheries in the Context of Food Security and Poverty Eradication. FAO.

Glavovic, B. (2006). The Evolution of Coastal Management in South Africa: Why Blood Is Thicker than Water. Ocean and Coastal Management, 49, 889-904.

Glavovic, B. (2016). Towards Deliberative Coastal Governance: Insights from South Africa and the Mississippi Delta. Regional Environmental Change, $16,353-365$.

Isaacs, M. (2006). Small-Scale Fisheries Reform: Expectations, Hopes and Dreams of 'a Better Life for All'. Marine Policy, 30, 51-59. https://doi. org/10.1016/j.marpol.2005.06.010

Kalikoski, D. C., Jentoft, S., Charles, A., Herrera, D. S., Cook, K., Béné, C., \& Allison, E. H. (2018). Chapter 2: Understanding the Impacts of Climate Change for Fisheries and Aquaculture: Applying a Poverty Lens. In M. Barange, T. Bahri, M. C. M. Beveridge, K. L. Cochrane, S. Funge-Smith, \& F. Poulain (Eds.), Impacts of Climate Change on Fisheries and Aquaculture: Synthesis of Current Knowledge, Adaptation and Mitigation Options (FAO Fisheries and Aquaculture Technical Paper No. 627) (pp. 19-39). FAO.

Kidd, M. (2013). Environment. In I. Currie \& J. De Waal (Eds.), The Bill of Rights Handbook. Juta.

Mbatha, P. N. (2018). The Influence of Plural Governance Systems on Rural Coastal Livelihoods: The Case of Kosi Bay. PhD, Environmental and Geographical Science Department, University of Cape Town. 
McIlgorm, A., Hanna, S., Knapp, G., Le Floc'H, P., Millerd, F., \& Pan, M. (2010). How Will Climate Change Alter Fishery Governance? Insights from Seven International Case Studies. Marine Policy, 34(1), 170-177.

Mohammed, E. Y., Steinbach, D., \& Steele, P. (2020). Fiscal Reforms for Sustainable Marine Fisheries Governance: Delivering the SDGs and Ensuring No One Is Left Behind. Marine Policy, 93, 262-270.

Mokwena, L. (2009). Municipal Responses to Climate Change in South Africa: The Case of eThekwini, the City of Cape Town, and the City of Johannesburg (Research Report 113). Center for Policy Studies. Available at: https://www. africaportal.org/publications/municipal-responses-to-climate-change-insouth-africa-the-case-of-ethekwini-the-city-of-cape-town-and-the-city-ofjohannesburg/. Accessed 9 May 2021.

Munzhedzi, H. (2020). Evaluating the Efficacy of Municipal Policy Implementation in South Africa: Challenges and Prospects. African Journal of Governance and Development, 9, 89-105.

Murcott, M. (2018). The Procedural Right of Access to Information as a Means of Implementing Environmental Constitutionalism in South Africa. In E. Daly \& J. May (Eds.), Implementing Environmental Constitutionalism: Current Global Challenges. Cambridge University Press.

Murray, W. E., \& Overton, J. D. (2011). Neoliberalism Is Dead, Long Live Neoliberalism? Neostructuralism and the International Aid Regime of the 2000s. Progress in Development Studies, 11(4), 307-319.

Pahl-Wostl, C., \& Knieper, C. (2014). The Capacity of Water Governance to Deal with the Climate Change Adaptation Challenge: Using Fuzzy Set Qualitative Comparative Analysis to Distinguish Between Polycentric, Fragmented and Centralized Regimes. Global Environmental Change, 29, 139-154.

Perine, C., \& Keuck, H. (2018). Building Urban Resilience to Climate Change: A Review of South Africa. Prepared for the United States Agency for International Development: Chemonics International Inc.

Raemaekers, S., \& Sowman, M. (2015). Community-Level Socio-Ecological Vulnerability Assessments in the Benguela Current Large Marine Ecosystem. (Fisheries and Aquaculture Circular No. 1110). Food and Agriculture Organization of the United Nations. Available at: http://www.fao. org/3/a-i5026e.pdf. Accessed 9 May 2021.

Reddy, Y., \& Wolpe, P. (2017). Sustainable Energy Solutions for South African Local Government: A Practical Guide. Sustainable Energy Africa. Available at: http:// www.cityenergy.org.za/uploads/resource_434.pdf. Accessed 9 May 2021. 
RSA. (1996). The Constitution of the Republic of South Africa. Government Printers. RSA. (2002). National Disaster Management Act No. 57 of 2002. Government Printers.

RSA. (2008). The National Environmental Management: Integrated Coastal Management Act No. 24 of 2008. Government Printers.

Ruiz-Díaz, R., Liu, X., Aguión, A., Macho, G., deCastro, M., Gómez-Gesteira,

M., \& Ojea, E. (2020). Social-Ecological Vulnerability to Climate Change in Small-Scale Fisheries Managed Under Spatial Property Rights Systems. Marine Policy, 121, 104192. https://doi.org/10.1016/j.marpol.2020.104192 Schlosberg, D. (2013). Theorising Environmental Justice: The Expanding Sphere of a Discourse. Environmental Politics, 22, 37-55.

Sowman, M. (2006). Subsistence and Small-Scale Fisheries in South Africa: A Ten-Year Review. Marine Policy, 30(1), 60-73. https://doi.org/10.1016/j. marpol.2005.06.014

Sowman, M. (2020). Participatory and Rapid Vulnerability Assessments to Support Adaptation Planning in Small-Scale Fishing Communities of the Benguela Current Large Marine Ecosystem. Environmental Development, 36. Sowman, M., \& Cardoso, P. (2010). Small-Scale Fisheries and Food Security Strategies in Countries in the Benguela Current Large Marine Ecosystem (BCLME) Region: Angola, Namibia and South Africa. Marine Policy, 34, 1163-1170.

Sowman, M., \& Malan, N. (2018). Review of Progress with Integrated Coastal Management in South Africa Since the Advent of Democracy. African Journal of Marine Science, 40, 121-136.

Sowman, M., \& Raemaekers, S. (2018). Socio-Ecological Vulnerability Assessment in Coastal Communities in the BCLME Region. Journal of Marine Systems, 188, 160-171.

Sowman, M., \& Sunde, J. (2021). A Just Transition? Navigating the Process of Policy Implementation in Small-Scale Fisheries in South Africa. Marine Policy. (Under Review).

Sowman, M., Raemaekers, S., \& Sunde, J. (2014a). Shifting Gear. A New Governance Framework for Small-Scale Fisheries in South Africa. In M. Sowman \& R. Wynberg (Eds.), Governance for Justice and Environmental Sustainability: Lessons Across Natural Resources Sectors in Sub-Saharan Africa (pp. 200-219). Routledge.

Sowman, M., Sunde, J., Raemaekers, S., \& Schultz, O. (2014b). Fishing for Equality: Policy for Poverty Alleviation for South Africa's Small-Scale Fisheries. Marine Policy, 46, 31-42. 
Sunde J., \& Erwin, K. (2020). Cast Out: The Systematic Exclusion of The KwaZulu-Natal Subsistence Fishers from the Fishing Rights Regime (Policy Research Report). Prepared for KZN Subsistence Fishing Forum and South Durban Community Environmental Alliance (SDCEA).

Sunde, J., Sowman, M., Smith, H., \& Wicomb, W. (2013). Emerging Proposals for Tenure Governance in Small-Scale Fisheries in South Africa. Land Tenure Journal, 1, 118-144.

Van Niekerk, D. (2006). Disaster Risk Management in South Africa: The Function and the Activity - Towards an Integrated Approach. Politeia, 25, 95-115.

Open Access This chapter is licensed under the terms of the Creative Commons Attribution 4.0 International License (http://creativecommons.org/licenses/ by/4.0/), which permits use, sharing, adaptation, distribution and reproduction in any medium or format, as long as you give appropriate credit to the original author(s) and the source, provide a link to the Creative Commons licence and indicate if changes were made.

The images or other third party material in this chapter are included in the chapter's Creative Commons licence, unless indicated otherwise in a credit line to the material. If material is not included in the chapter's Creative Commons licence and your intended use is not permitted by statutory regulation or exceeds the permitted use, you will need to obtain permission directly from the copyright holder.

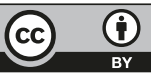

